\title{
Identification of the Origin of Domesticated Red Jungle Fowl by the Community in Bengkulu Province, Indonesia
}

\author{
Johan Setianto $^{1,2, *}$, Sutriyono ${ }^{1}$, Suharyanto ${ }^{1}$ \\ ${ }^{1}$ Department of Animal Husbandry, Faculty of Agriculture, University of Bengkulu, \\ ${ }^{2}$ Postgraduate Program in Natural Resources and Environmental Management, Faculty of Agriculture, \\ University of Bengkulu. Jl. W.R. Supratman Kandang Limun, Bengkulu 38371. Tel./Fax. + 62-736-21290 \\ *Corresponding author. Email : jsetbkl@yahoo.com
}

\begin{abstract}
Red jungle fowl is one of the important species that has the function of ecology, economy, and aesthetics. The red jungle fowl and their offsprings have an important role for rural communities. The communities in Bengkulu Province had done a domestication of the red jungle fowl. Until now, the conservation of the red jungle fowl in a community was not much studied. This study aimed to identify informations about the origin of the red jungle fowl breeds, the origin of purchase of breeds, the equipment used for hunting and the breeds purity. Respondents selection was conducted by using a snowball sampling method. The data were obtained from the breeders selected as respondents by using a combination of in-depth interviews, questionnaires and a direct observation. The results showed that $62.27 \%$ respondents obtained the breeds from buying, $11.98 \%$ from hunting, $11.38 \%$ from conferral, $13.77 \%$ from buying and hunting, and $0.60 \%$ from buying and conferral. From respondents who did the breeds buying, $77.88 \%$ respondents bought the red jungle fowl from the breeders, $22.12 \%$ bought from hunters. Breeds were purchased by the respondent were $0.96 \%$ hens, $72.12 \%$ cocks, $3.84 \%$ chiks, $22.12 \%$ hens/cocks, and $0.96 \%$ hens/cocks/chicks. Hunting activities were undertaken by $11.98 \%$ respondents, while $88.02 \%$ did not practice hunting activities. Respondents who did hunting activities, $10 \%$ used a net, $25 \%$ racit equipment, $15 \%$ trap and $50 \%$ used a combination of net and racit. Breeds obtained by respondents, $23.95 \%$ the red jungle fowl, $67.67 \%$ offsprings and $8.38 \%$ the red jungle fowl and offsprings. The origins of the red jungle fowl obtained from nature by hunting and from the community by buying and conferral.
\end{abstract}

Keywords: red jungle fowl, the origin, breeds, hunting

\section{INTRODUCTION}

Red jungle fowl is the ancestor of the domesticated chicken that exists at this moment [1] [2]. Red jungle fowl live in secondary forests, especially forests that have been burned for agricultural purposes [3], prefer living in wild environments, cultivated land, and human habitats, living perched on tree branches with a height of $5 \mathrm{~m}$ above ground level and live in groups a total of 4-8 individuals per group [4]. Red jungle fowl consuming different types of vegetation such as Palm fruits, papaya, cempedak fruit, rambutan fruit, nuts, and seeds of grasses and some species of invertebrate animals [5]. On the other hand, the red jungle fowl is a prey or food for predators [6]. The existence of habitat destruction, uncontrolled hunting, and predatory predation is thought to be the cause of declining populations of the red jungle fowls leading to extinction $[6,7,8]$. The extinction of red jungle fowl will result in the extinction of burgo chicken. Red jungle fowl is the parent of burgo chicken (Bengkulu's local chickens) which is preserved by the people of Bengkulu $[9,10,11,12]$. Whereas red jungle fowl is a vital asset for community in the province of Bengkulu [13]. Land conversion and habitat destruction lead to loss of shelter, feeding grounds, playgrounds, nesting sites and egglaying, brooders, and parenting. This causes the migration to another place temporarily or permanently. If in the new habitat is able to adapt to the environment then the chicken will survive, but if not then the chicken will die. In addition, the hunting of red jungle fowl by the community continues with the use of traditional tools and modern tools and catches of live chickens and dead chickens $[6,14,15]$. Further explained that the red jungle fowl was caught alive and then partially preserved, partially consumed, and some for sale. The red jungle fowl from catches that live and preserved by the community must be able to adapt to the new environment. If able to adapt to the new environment then the red jungle fowl will pass to live, if not able then the red jungle fowl will die. Based on the conservation status issued by IUCN (International Union for the Conservation of Nature and Natural Resources) on the IUCN Red List, the status of the red jungle fowl is included in LC (Least Concern) status or low risk [16].The Red jungle fowl is one of the wildlife that live 
in forests and plantations in Bengkulu, Sumatra, Indonesia and plays an important role in producing new poultry species $[6,17,18]$. The result of matting between red jungle fowl and local chicken has produced offspring called burgo chicken which is a Bengkulu's local chicken $[9,12,19]$. The red jungle fowls and their offspring are exploited by humans as pets with the aim of being a genetic source, food source, ornamental animals, and hunting animals. Therefore, many communities raise red jungle fowl as well as their offspring $[13,20]$. The red jungle fowl and their offspring are reared by day and night, kept at night and left at noon, and left in day and night [21]. Feed is given to red jungle fowl different between breeders ranging from one type to five types of feed. Until now red jungle fowl and their offspring are still raised by the community in Bengkulu for various purposes. The basic information on the origin of red jungle fowl is not yet known [22].

The purpose of this study was to identify the origin of the red jungle fowl raised by the community in Bengkulu Province, Indonesia and how to obtain it.

\section{MATERIALS AND METHODS}

The research was conducted in Bengkulu Province. Research location is determined intentionally (purposivelly), based on information existing breeders who raise the red jungle fowl. Based on the observations, the selected research locations are North Bengkulu District, Central Bengkulu district, Seluma district, and Bengkulu City.

Respondents are breeders who raise red jungle fowl and, or their offspring. Respondents selection were conducted by using a snowball sampling method. With this method obtained 167 respondents.

The data was obtained from the breeders selected as respondents by using a combination of in-depth interviews, questionnaires and a direct observation. The data collected was the origin of breeds (buying, hunting, or conferral), the origin of breeds purchase, hunting equipment, and the purity of breeds. The data obtained are presented in the form of tables and drawings and analyzed descriptively.

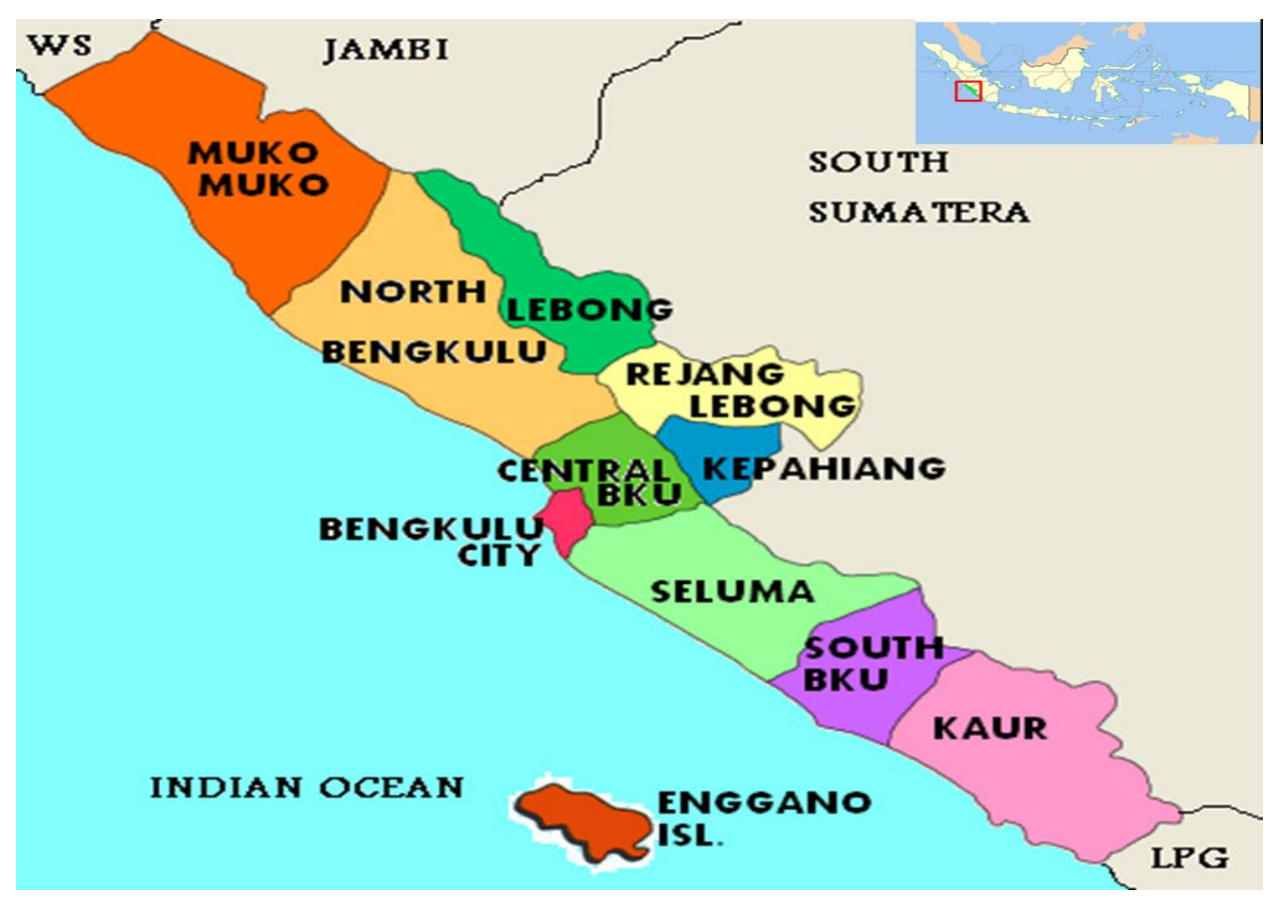

Fig. 1: shows the map of the province of Bengkulu and the location where the research was conducted

\section{RESULTS AND DISCUSSION}

\subsection{General Condition of Research Sites}

Bengkulu Province is one of the provinces on the island of Sumatra, Indonesia and is located at $2^{\circ} 16^{\prime}-3^{\circ} 31^{\prime}$ South Latitude and $101^{\circ} 01^{\prime}-103^{\circ} 41^{\prime}$ East Longitude, with an area of 19,919.33 square kilometers. Administratively, the provincial government of Bengkulu is divided into 9 districts and 1 city. To the North, it borders with the province of West Sumatra, Indonesia Ocean and Lampung Province in the south, Indonesia Ocean in the west, Jambi Province and South Sumatra Province in the east. Bengkulu Province is directly adjacent to the Indonesian Ocean on the coastline of approximately 525 kilometers. The eastern part of Bengkulu province is hilly with a fertile plateau, while in the west is a relatively narrow lowland, extending from north to south interspersed with bumpy regions. Agriculture is an important sector in Bengkulu. Coverage of agricultural activities includes agriculture, animal husbandry, hunting, agricultural services, forestry, logging and fisheries (Bengkulu in Figure, 2015). Land in the province of Bengkulu is dominated by forests and plantations are still very widely spread in several areas. This condition can support the life of red jungle fowl to thrive. 


\subsection{Characteristics of the Red Jungle Fowl Breeders in Bengkulu, Indonesia}

Characteristics of the Red jungle fowl breeders in Bengkulu covering employment, education of breeders, and the purpose of raising red jungle fowl is indicated in Table 1 .

Table 1. Characteristics of the red jungle fowl breeders

\begin{tabular}{|c|c|c|c|}
\hline No & Variable/Description & $\begin{array}{c}\text { Number } \\
\text { of } \\
\text { breeders }\end{array}$ & $\begin{array}{c}\text { Percentage } \\
(\%)\end{array}$ \\
\hline 1 & $\begin{array}{l}\text { Job } \\
\text { Gov. } \\
\text { employees/Police/Army } \\
\text { Retired } \\
\text { Private } \\
\text { Labor } \\
\text { Farmer } \\
\text { Total }\end{array}$ & $\begin{array}{c}14 \\
3 \\
57 \\
5 \\
88 \\
167\end{array}$ & $\begin{array}{c}8.38 \\
1.80 \\
34.13 \\
2.99 \\
52.69 \\
100\end{array}$ \\
\hline 2 & $\begin{array}{l}\text { Education } \\
\text { No school } \\
\text { Elementary school } \\
\text { Junior high school } \\
\text { Senior high school } \\
\text { College/Universities } \\
\text { Total }\end{array}$ & $\begin{array}{c}1 \\
49 \\
46 \\
54 \\
17 \\
167\end{array}$ & $\begin{array}{c}0.60 \\
29.34 \\
27.54 \\
32.34 \\
10.18 \\
100\end{array}$ \\
\hline 3 & $\begin{array}{l}\text { The purpose of raising } \\
\text { Hobby } \\
\text { Hobby, development, } \\
\text { bussines } \\
\text { Total }\end{array}$ & $\begin{array}{c}131 \\
\\
36 \\
167\end{array}$ & $\begin{array}{c}78.44 \\
21.56 \\
100\end{array}$ \\
\hline
\end{tabular}

The main job of the Red jungle fowl breeders in Bengkulu is mostly farming $(52.69 \%$ breeders) and private $(34.13 \%$ breeders). While the work of other breeders is relatively small. Farm labor is dominated by agriculture and private sector, where agriculture and private sector are the preferred employment opportunities for the community in Bengkulu Indonesia in accordance with the availability of natural resources and the natural environment that support the field. Environmental conditions affect a person's interest in raising red jungle fowl. The village environment with the work of the farming community, the chicken is a good sideline for cultivation. Village environmental conditions, especially those close to plantations and forestry, have similar climatic conditions to the surrounding forests. The village is also a source of feed for poultry both feed material from plant and animal feed material. Therefore, the village is a good place for the growth and development of red jungle fowl.

The breeders' education ranges from elementary school to university, namely elementary school is $29.34 \%$ farmers, junior high school is $27.54 \%$ breeders, senior high school $32.34 \%$ breeders, and universities are $10.18 \%$ breeders. Although the education of farmers is diverse, there is a breeder with the level of education at the university then the transformation of science can occur continuously among the breeders.

The purpose of raising red jungle fowl and the offspring of red jungle fowl by breeders is not just for food production, but also as a hobby, as an ornamental chicken, as hunting chicken, and as a business commodity [8]. In this study, the purpose of raising red jungle fowl is a hobby (78.44\% breeders), and for development, business and hobby ( $21.56 \%$ breeders).

\subsection{The Origin of Red Jungle fowl}

Red jungle fowl and their offspring kept by breeders in Bengkulu Province are listed in Table 2. Red jungle fowl reared by farmers comes from catching in nature (hunting), buying, and conferral, and a combination of these three ways.

Table 2. The origin of red jungle fowl reared by breeders in bengkulu, indonesia

\begin{tabular}{|c|c|c|c|}
\hline No & Variable/Description & $\begin{array}{c}\text { Number } \\
\text { of } \\
\text { breeders }\end{array}$ & $\begin{array}{c}\text { Percentage } \\
(\%)\end{array}$ \\
\hline 1 & $\begin{array}{l}\text { The origin of breeds } \\
\text { Hunting } \\
\text { Buying } \\
\text { Buying and hunting } \\
\text { Conferral } \\
\text { Conferral and buying } \\
\text { Total }\end{array}$ & $\begin{array}{c}20 \\
104 \\
23 \\
19 \\
1 \\
167\end{array}$ & $\begin{array}{c}11.98 \\
62.27 \\
13.77 \\
11.38 \\
0.60 \\
100\end{array}$ \\
\hline 2 & $\begin{array}{l}\text { The origin of breeds' } \\
\text { purchase } \\
\text { Hunters } \\
\text { Breeders } \\
\text { Total } \\
\end{array}$ & $\begin{array}{c}23 \\
81 \\
104\end{array}$ & $\begin{array}{c}22.12 \\
77.88 \\
100\end{array}$ \\
\hline 3 & \begin{tabular}{l}
\multicolumn{1}{c}{$\begin{array}{c}\text { Breeds were } \\
\quad \text { purchase }\end{array}$} \\
Hens \\
Cocks \\
Chicks \\
Hens/cocks \\
Hens/cocks/chicks \\
Total
\end{tabular} & $\begin{array}{c}1 \\
75 \\
4 \\
23 \\
1 \\
104\end{array}$ & $\begin{array}{c}0.96 \\
72.12 \\
3.84 \\
22.12 \\
0.96 \\
100\end{array}$ \\
\hline 4 & $\begin{array}{l}\quad \text { Purity of breeds } \\
\text { Red jungle fowl } \\
\text { Offspring of red } \\
\text { jungle fowl } \\
\text { Red jungle fowl/ } \\
\text { offspring } \\
\text { Total }\end{array}$ & $\begin{array}{c}40 \\
113 \\
14 \\
167\end{array}$ & $\begin{array}{c}23.95 \\
67.67 \\
8.38 \\
100\end{array}$ \\
\hline
\end{tabular}

In this study, the origin of red jungle fowl reared by breeders obtained from hunting were $11.98 \%$ of the total breeders, while the remaining $88.02 \%$ were from buying $(62,27 \%)$, buying and hunting $(13.77 \%)$, conferral $(11.38 \%)$, and conferral and buying $(0.60 \%)$ (Table 2$)$

In addition to the way of hunting, the origin of red jungle fowl raised by farmers is obtained from the purchase. The breeds purchased by the breeder are red jungle fowl and the offspring of red jungle fowl. The number of breeders who obtain breeds by buying is $62.27 \%$ of the total breeders or 104 breeders. Of these, the breeders who bought the chickens from the hunters were $22.12 \%$ or 23 farmers, and purchased breeds from breeders were $77.88 \%$ or 81 farmers (Table 2). Breeds obtained by buying are more benign chicken than pure red jungle fowl, so maintenance is easier. This is done by farmers with the aim of production (meat, eggs, chicks), for ornamental chicken, and chicken for hunting. Red jungle fowl and their offspring traded by breeders 
have long been nurtured by humans and have adapted to the environment and are relatively benign so maintenance is easier both feeding and cages. In nature, red jungle fowl feeds on various types of fodder both plants and animals either. Chicken feed ingredient is free to choose to meet the necessary nutrients to his body [5] and red jungle fowl live on trees and perched on a tree branch with a height of approximately 5 meters above ground level [4]. Raising of red jungle fowl obtained by hunting in narrow cages and feeds that do not fit the habit in the wild will cause pressure on the chickens, resulting in death. Instead, the red jungle fowl has long been kept by breeders only given feed derived from plants in the form of grain like corn, paddy, rice, in a narrow cage can survive and reproduce until recently [21]. In addition, chickens that have long been reared by breeders have been partly benign and able to find their own feed in nature during the day around the dwellers of breeders and went home cage in the afternoon [21] (Sutriyono et al. 2017). It encourages red jungle fowl-keeping communities prefer buying the offspring of red jungle fowl which have long raised. While breeders who buy chickens from hunters are to get a pure red jungle fowl to be crossed with descendants of red jungle fowl, so obtained offspring that are genetically closer to his ancestors. However, pure red jungle fowl is so wild, so difficult to raise, and only experienced breeders who keep pure red jungle fowl.

The breeds are purchased by breeders in the form of hens, cocks, chicks, and the combination of to the three. Breeders who buy the breeds in the form of Hens was $0.96 \%$ or one breeders, breeders who buy breeds in the form of cocks was $72.12 \%$ or 75 breeders, breeders who buy breeds in the form of the chicks is $3.84 \%$ or 4 people, breeders who buy breeds in the form of Hens/Cocks is $22 \%$ or 23 people, and breeders who buy hens/cocks/chicks is $0.96 \%$ or one person breeders (Table 2). Some of the Red jungle fowl breeders get breeds by purchasing and hunting. The way done by $13.77 \%$ of the total breeder or 23 people. The way is done by breeders who do raise with the purpose to the development of the red jungle fowl leading to commercial farms, and breeders who have a hobby of the red jungle fowl hunting. The origin of the breeds of the red jungle fowl is from the grant or conferral, totaling $11.38 \%$ of the total breeders or 19 farmers.

Based on its authenticity, the breeder who keeps the original red jungle fowl is $23.95 \%$ of the total breeders or 40 farmers, who keep the offspring of red jungle fowl is $67.67 \%$ or 113 breeders and breeders who keep the original and the offspring of red jungle fowl is $8.38 \%$ or 14 farmers (Table 2). Breeders who raise the offspring red jungle fowl more than the original red jungle fowl. Many breeders prefer to buy cock breeds rather than buying hens and chicks. Cocks are purchased by a breeder aiming for ornamental chicken, hunting chicken, for males, while hens are bought by breeders aiming for egg and chick production. Red jungle fowl has been nurtured by community in Bengkulu for the purpose as an ornamental chicken because of its distinctive crow, as hunting animal, and as stud [6]. While the purchase of chicks by the breeders aims to get pet chickens in an easy way, so obtained a red jungle fowl (offspring) adults are relatively short. Red jungle fowl that have been matted with local chicken or offspring of red jungle produce fertile eggs [21].

Most breeders did not hunt red jungle fowl in the wild because they did not have the skills nor the expertise to catch red jungle fowl. Furthermore, the figure 2 can be seen that only $11.98 \%$ of respondents who do hunting activities, while the remaining $88.02 \%$ did not do hunting activities. In another study [20] have found that hunting activities were undertaken by $40 \%$ respondents, while $60 \%$ did not practice hunting activities. Meanwhile [22] showed that hunting activities undertaken by $65,22 \%$ respondents, while the remaining $34,78 \%$ did not hunting activities.

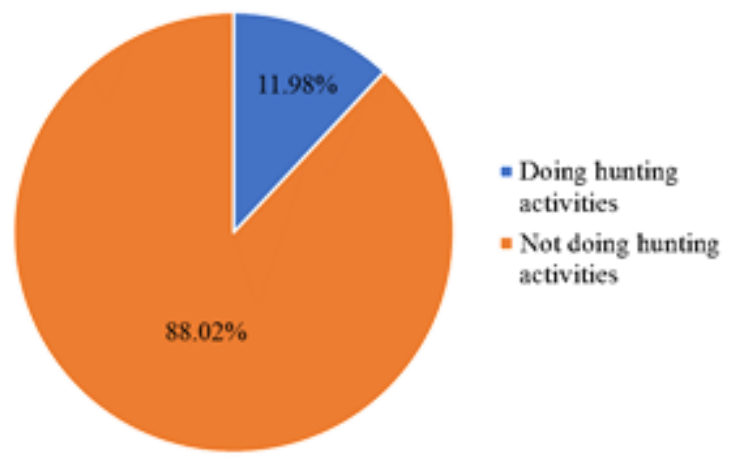

Fig. 2 Breeders who do the red jungle fowl hunting activities in nature.

The hunter catches the red jungle fowl by equipment such as nets, racits, and traps; Respectively are $10 \%, 25 \%, 15 \%$, and $50 \%$ using nets and racit. From respondents who did the hunting activities, $10 \%$ used a net, $30 \%$ used racit equipment and $60 \%$ used a combination of net and racit. Meanwhile, Setianto et al. (2016) found that in Seluma District, the majority of respondents $(85.72 \%)$ used a combination of decoys with racit and nets. Only a small fraction $(7.14 \%)$ of respondents using decoys and nets, in addition to $7.14 \%$ using decoys and racit. In another study, [6] found that in Central Bengkulu District, $10 \%$ using decoys and nets, $30 \%$ using decoys and racit, while the rest $(60 \%)$ using a combination of decoys with nets and racits. The use of these equipment obtained by the chicken in a state of life and cock male sex.

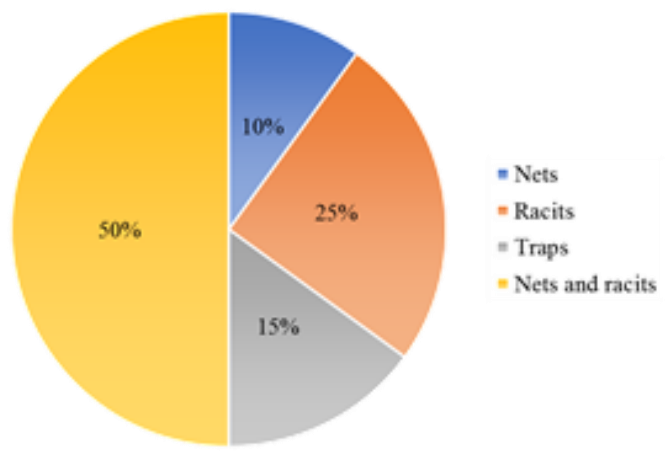

Fig. 3 The red jungle fowl hunting equipment used to capture the red jungle fowl in the forest by respondent

All equipment used to catch red jungle fowl always used decoy chickens. The decoy chickens are offspring of red jungle fowl. In Figure 2 can be seen the decoy chickens raised by the community 


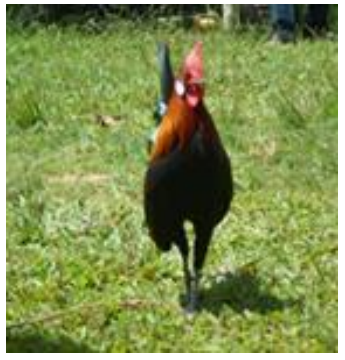

(a)

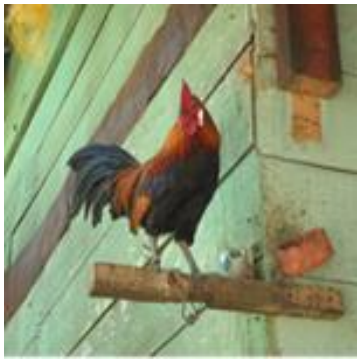

(b)
Fig. 2 : Decoy chicken for red jungle fowl hunting, (a) decoy chicken is sunbathed under the sunshine, and (b) decoy chicken is perched.
The chicken obtained from the hunt is a red jungle fowl. Red jungle fowl obtained from hunting are very wild, so hunters of red jungle fowl do not keep much of their catch [6]. The wild nature of red jungle fowl is also found in the offspring of the red jungle fowl, although it has been well preserved since incubation [23]. In addition to the above mentioned poaching methods, there are several other ways to catch red jungle fowl in nature, such as airsoft gun, rifles, and catapults $[14,15]$. The catching method is not obtained by the red jungle fowl in a state of life, so the catch is not environmentally friendly and leads to a decrease in the red jungle fowl population.
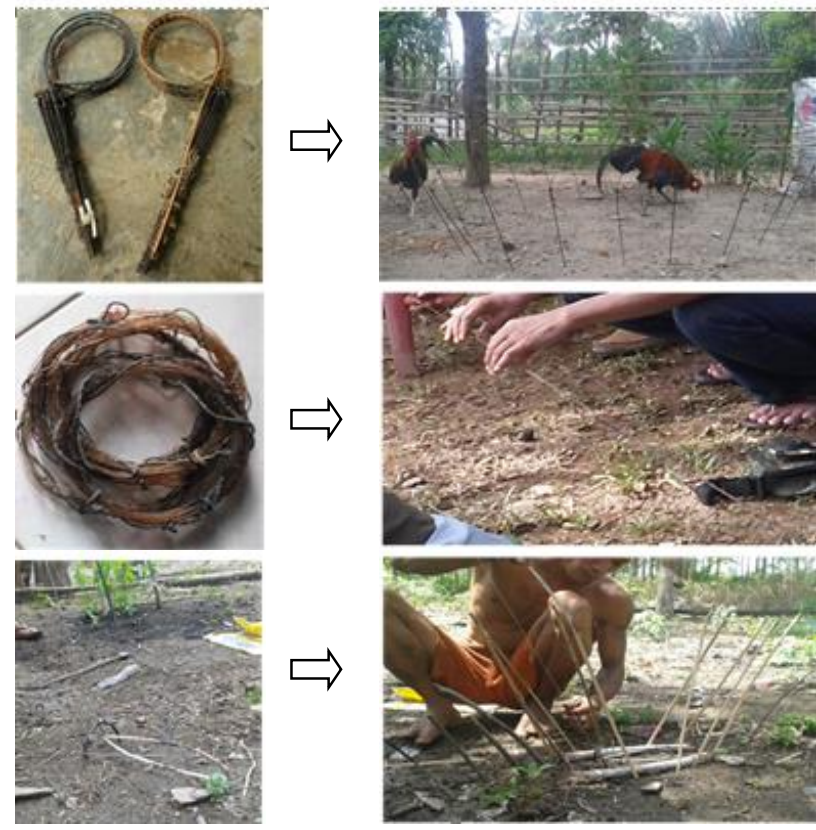

(a)

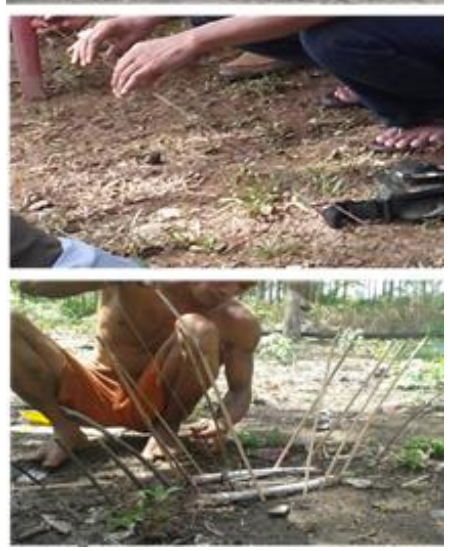

(b)

(c)

Fig. 3: The red jungle fowl hunting tools used to capture the red jungle fowl by the respondents and how to install the equipment for hunting, (a) racit, (b) net and (c) trap.

\section{CONCLUSION}

From the research, it can be concluded that the origins of the red jungle fowl obtained from nature by hunting in the forests or in plantations area, as well as from surrounding communities either by way of buying or conferral. The equipment used for hunting in the form of racit, nets, traps or a combination.

\section{ACKNOWLEDGMENT}

We would like to thank to the Ministry of Research, Technology and Higher Education for funding this research. This study is part of the research scheme "PTUPT UNIB". We also express our gratitude to Institute of Research and Community Service (LPPM) University of Bengkulu.

\section{REFERENCES}

[1] M. Fernandes, Mukesh, S. Sathyakumar, R. Kaul, R. S. Kalsi and D. Sharma, Conservation of red jungle fowl Gallus gallus in India. International Journal of Galliformes Conservation, 2009, vol 1, pp. 94-101. http://www.birdlife.org on 8/03/2014.

[2] S. Sulandari, dan M.S.A. Zein, Analisis D-loop DNA Mitokondria untuk memposisikan Ayam Hutan Merah dalam Domestikasi Ayam di Indonesia, Media Peternakan, 2009, 32(1): 31-39.

[3] N. E. Collias, and E.C.Collias, A field study of the Red Jungle Fowl in north-central India. The Condor, 1967, vol 69(4), pp. 360-86.

[4] F. Akrim, T.Mahmood, M.S. Awan, S.Q. Butt, D.E. Shawar, M.A. Asadi and I. Zangi, Habitat preference and roosting behaviour of the Red Junglefowl Gallus gallus (Aves: Galliformes: Phasianidae) in Deva Vatala National Park, Azad Jammu \& Kashmir, Pakistan. Journal of Threatened Taxa |www.threatenedtaxa.org, 2016, 8(9): 9138-9143.DOI: http://dx.doi.org/10.11609/jott.2256.8.9.9138-9143. 
[5] M.I. Arshad and M. Zakaria, Roosting Habits of Red Junglefowl in Orchard Area. Pak. j. life soc. sci, 2009, 7(1) :86-89.

[6] J. Setianto, Sutriyono, H. Prakoso and B. Zain, Identification of the Origin of the Red Jungle Fowl Reared by Community in Seluma District, Jurnal Sain Peternakan Indonesia, Vol. 11 No. 2, pp. 141-152, JuliDesember 2016.

[8] Sutriyono, J. Setianto, H. Prakoso, Production and population of the red jungle fowl domestication in North Bengkulu District and population development scenario. Pros Sem Nas Masy Biodiv Indon Volume 2, Nomor 2, Desember 2016, pp. 226-231. DOI: 10.13057/psnmbi/m020218.

[9] J. Setianto, Ayam Burgo. Ayam Buras Bengkulu. IPB Press Bogor, 2009.

[10] J. Setianto, Potensi dan strategi pengembangan ayam burgo. Prosiding Seminar Nasional Peternakan: Potensi Sumber Daya Ternak Lokal Untuk Membangun Kemandirian Pangan Hewani dan Kesejahteraan Masyarakat. Padang, 2013, I: 15-20.

[11] J. Setianto dan Warnoto, Performa reproduksi dan produksi ayam burgo betina. UNIB Press, Bengkulu, 2010. 2010.

[12] J. Setianto, H. Prakoso dan Sutriyono, Dynamics of Burgo Chicken Population and Development Strategy in Bengkulu. Research Report. Faculty of Agriculture. University of Bengkulu, 2013.

[13] J. Setianto, H. Prakoso, Sutriyono, Red jungle fowl domestication studies of community-based and its development strategy in Bengkulu. Research report. Universitas Bengkulu, Bengkulu, 2014.

[14] A. Aiyadurai, Bird hunting in Mishmi Hills of Arunachal Pradesh, North-Eastern India. Indian Birds, 2012, 7(5): 134-137.

[15] W. Liang, Y. Cai, CC. Yang, Extreme levels of hunting of birds in aremote village of Hainan Island, China. Bird Conserv Int, 2013, vol. 23, pp. 45-52.

[16] Bird Life International, IUCN Red List for birds, 2014.
[17] J. Setianto, Sutriyono, H. Prakoso , dan B. Zain, Red Jungle Fowl Development Scenarios for poultry farmers in Bengkulu Coastal Communities. Proceeding of International Seminar and Expo. "Sustainable Utilization of Coastal Resources In Tropical Zone (Isecoastal)" 19-20 October 2016. Faculty of Agriculture. University of Bengkulu, 2017 a I : 419 - 425.

[18] J. Setianto, B. Zain, Sutriyono, H. Prakoso, Domestication: A case study of red jungle fowl coops management by the communities in Bengkulu. Jurnal Sain Peternakan Indonesia Vol. 13 No. 3 Juli-September 2018. Pp. 274-281.

[19] J. Setianto, Sutriyono, H. Prakoso, B. Zain, R. Adwiyansyah, A.H.K. Amrullah. 2019. Short communication: Phenotypic diversity of male Burgo chicken from Bengkulu, Indonesia. Biodiversitas Volume 20, Number 2, February 2019, pp. 532-536. DOI: $10.13057 /$ biodiv/d200232.

[20] J. Setianto, B. Zain, Sutriyono, H. Prakoso, Domestication of red jungle fowl: A case study of the red jungle fowl chick procurement by the communities in Central Bengkulu, Indonesia. Biodiversitas Volume 18 , Number 1 , January 2017, 2017 , pp. 183-189 DOI: 10.13057/biodiv/d180125.

[21] Sutriyono, J. Setianto, H. Prakoso, B. Zain, Conservation and utilization of red jungle fowl in the coastal areas of North Bengkulu. Proceeding of International Seminar and Expo on Sustainable Utilization of Coastal Resources in Tropical Zone (Isecoastal). 19-20 October, 2016, Faculty of Agriculture, University of Bengkulu, 2017. I: $382-388$.

[22] J. Setianto, Prakoso H, Sutriyono, Domestication of red jungle fowl: A case study of red jungle fowl poaching by communities in North Bengkulu. Pros Sem Nas Masy Biodiv Indon, 2015, 1 (2): 207-212.

[23] Brisbin, I. L. and A. T. Peterson, Playing chicken with red jungle fowl: identifying phenotypic markers of genetic purity in Galus gallus. Animal Conservation, 2007, vol 10 (4), pp.429-435. 